\title{
The Extent and Impact of Outsourcing: Evidence from Germany
}

\author{
Craig Aubuchon, Subhayu Bandyopadhyay, and Sumon Kumar Bhaumik
}

\begin{abstract}
The authors use data from several sources, including plant-level data from the manufacturing sector in Germany, to expand the literature on outsourcing. They find that, in Germany, the extent of outsourcing among manufacturing industries is higher than among service industries and that the outsourcing intensity of these industries did not change much between 1995 and 2005. They also find a statistically significantly positive impact of industry-level outsourcing intensity on German plant-level labor productivity for both 2000 and 2005. The estimated economic impact of outsourcing on plant-level productivity is also fairly significant. (JEL F16, D24)
\end{abstract}

Federal Reserve Bank of St. Louis Review, July/August 2012, 94(4), pp. 287-304.

$\mathbf{T}$

his paper incorporates plant-level data from the manufacturing sector in Germany to expand the literature on the impact of outsourcing on firm-level productivity. The 2009 Capgemini Executive Outsourcing Survey (Wilmot, 2009) indicates that nearly threefourths of the (surveyed) executives believe that outsourcing enables firms to survive in today's global economy. They argue that outsourcing makes firms agile and flexible (60 percent), thereby making them better capable of facing competition, and that the money saved from outsourcing can facilitate growth (70 percent). However, in an era of high unemployment, criticism of outsourcing in the developed world is on the rise; and such criticism has found some support from academic research. Keuschnigg and Ribi (2009) demonstrated that outsourcing increases both unemployment and the labor income risk of unskilled workers in the home country. In addition, Zhang (2011) argued that even if outsourcing increases employment in the aggregate, it may cause net welfare loss through resource misallocation. Such findings have resulted in a wide range of propositions to reduce outsourcing, either by disincentivizing

Craig Aubuchon is a former research associate at the Federal Reserve Bank of St. Louis and a recent graduate of the Indiana University School of Public and Environmental Affairs. Subhayu Bandyopadhyay is a research officer and economist at the Federal Reserve Bank of St. Louis. Sumon Kumar Bhaumik is a reader in the Economics and Strategy Group at Aston Business School, Aston University, Birmingham, United Kingdom, and a research fellow at the William Davidson Institute at the University of Michigan, Ann Arbor, Michigan, and IZA (Institute for the Study of Labor) in Bonn, Germany. The authors thank the Institute for Employment Research (IAB) at Nuremberg, Germany, for providing the data and facilitating the empirical estimation and thank Lowell Rickets for excellent research assistance. They also thank Daniela Hochfellner and Peter Jacobebbinghaus of IAB for their continual support through the duration of the research and Gyde Neumann of Germany's Monopolkomission for providing the data on industry-level competition.

( ) 2012, The Federal Reserve Bank of St. Louis. The views expressed in this article are those of the author(s) and do not necessarily reflect the views of the Federal Reserve System, the Board of Governors, or the regional Federal Reserve Banks. Articles may be reprinted, reproduced, published, distributed, displayed, and transmitted in their entirety if copyright notice, author name(s), and full citation are included. Abstracts, synopses, and other derivative works may be made only with prior written permission of the Federal Reserve Bank of St. Louis. 


\section{Aubuchon, Bandyopadhyay, Bhaumik}

\section{Table 1}

\section{Review of Literature on Impact of Outsourcing}

\begin{tabular}{lll} 
Author & Country (year) & \multicolumn{1}{c}{ Industry } \\
\hline $\begin{array}{l}\text { Amiti and Wei } \\
(2006)\end{array}$ & $\begin{array}{l}\text { U.S. } \\
(1992-2000)\end{array}$ & Manufacturing \\
& & \\
Bachmann and & $\begin{array}{l}\text { Germany } \\
\text { Braun (2011) }\end{array}$ & $\begin{array}{l}\text { Manufacturing and } \\
\text { services sectors }\end{array}$ \\
& & \\
Criscuolo and & U.K. & \\
Leaver (2005) & (2000-03) & Manufacturing and \\
\end{tabular}

\section{Impact of outsourcing on performance}

Both servicing and materials outsourcing had a significant impact on productivity growth in the U.S., but the impact of servicing outsourcing was much greater than the impact of materials outsourcing and accounted for 10 percent of the growth in labor productivity.

Overall, outsourcing increases job stability, much more so in the services sector than in the manufacturing sector. However, the impact of outsourcing varies by skill level of workers, with medium-skilled and older workers at higher risk of transitioning to non-employment.

Firms that outsource are larger and more capital intensive, are bigger users of information and communications technology (ICT) capital, and have more international links than firms that do not outsource. The impact of outsourcing on productivity is positive but not large; a 10 percent increase in outsourcing increases total factor productivity by 0.37 percent. The effect of offshoring is caused largely by firms that are domestic and not engaged globally.

Selected manufacturing

(1995-2003)

Jona-Lasinio (2008)

\begin{tabular}{|c|c|c|}
\hline $\begin{array}{l}\text { Egger and } \\
\text { Egger (2006) }\end{array}$ & $\begin{array}{l}\text { EU12 } \\
(1993-97)\end{array}$ & Manufacturing \\
\hline $\begin{array}{l}\text { Girma and Görg } \\
\text { (2004) }\end{array}$ & $\begin{array}{l}\text { United Kingdom } \\
(1980-92)\end{array}$ & $\begin{array}{l}\text { Selected } \\
\text { manufacturing }\end{array}$ \\
\hline
\end{tabular}

Görg and Hanley

Republic of Ireland Electronics (2004) (1990-95)

Görg and Hanley (2005)

Republic of Ireland (1990-95)
Offshoring within the same industry is beneficial for productivity growth, but there is no observable benefit from offshoring of services. The positive effect of offshoring on productivity is not robust to the choice of outsourcing measure; it disappears when the FH measure (described in Table 2) is used instead of the input-output-based measure.

International outsourcing has a negative marginal impact on value added per low-skilled worker in the short run but a positive marginal impact in the longer run.

Outsourcing may be driven by the objective to reduce cost, and foreign firms are more likely to outsource than domestic firms. Outsourcing is associated with growth of both labor productivity and total factor productivity at the firm level, but foreign firms are more likely to benefit than domestic firms.

Outsourcing can improve profitability of firms that are substantially larger than the average firm size, but there is no evidence of benefit for significantly smaller firms.

Outsourcing of materials can generate significant productivity gains, but such gains only accrue to firms with low export intensity.

it by using an appropriate tax policy or by directly imposing a cap on the proportion of jobs that can be sent abroad to offshore firms.

The economic and political concerns about unemployment and income fragility must be balanced against the need to ensure productivity growth. The deep post-2008 financial and economic crisis may have permanently reduced the production capacity of industrialized countries by as much as 4 percent (Directorate-General for Economic and Financial Affairs, 2009, and Furceri and Mourougane, 2009), such that a rapid rise in productivity growth might be the only 


\section{Table 1, cont'd}

\section{Review of Literature on Impact of Outsourcing}

\begin{tabular}{|c|c|c|c|}
\hline Author & Country (year) & Industry & Impact of outsourcing on performance \\
\hline $\begin{array}{l}\text { Görg, Hanley, and } \\
\text { Strobl (2008) }\end{array}$ & $\begin{array}{l}\text { Republic of Ireland } \\
(1990-98)\end{array}$ & Manufacturing & $\begin{array}{l}\text { International services outsourcing has a significant positive } \\
\text { effect on productivity, but (both domestic and foreign- } \\
\text { owned) exporters are likely to gain, with no evidence of } \\
\text { productivity gain for non-exporters. }\end{array}$ \\
\hline $\begin{array}{l}\text { Gorzig and } \\
\text { Stephan (2002) }\end{array}$ & $\begin{array}{l}\text { Germany } \\
(1992-2000)\end{array}$ & Manufacturing & $\begin{array}{l}\text { Both materials and services outsourcing have a positive } \\
\text { impact on return per employee. However, the impact on } \\
\text { profitability is asymmetric; materials outsourcing has a posi- } \\
\text { tive impact on profitability, while services outsourcing has a } \\
\text { negative impact. }\end{array}$ \\
\hline $\begin{array}{l}\text { Hijzen, Inui, and } \\
\text { Todo (2010) }\end{array}$ & $\begin{array}{l}\text { Japan } \\
(1994-2000)\end{array}$ & Manufacturing & $\begin{array}{l}\text { Outsourcing to foreign affiliates increases a firm's productivity, } \\
\text { but outsourcing to unaffiliated foreign firms does not have } \\
\text { such an effect. Indeed, outsourcing to unaffiliated foreign } \\
\text { affiliates has a negative impact on firms that are not multi- } \\
\text { nationals and those that do not export, even though the } \\
\text { impact on multinationals and exporting firms is non-negative. }\end{array}$ \\
\hline Kurz (2006) & $\begin{array}{l}\text { U.S. } \\
(1987-96)\end{array}$ & Manufacturing & $\begin{array}{l}\text { Outsourcing firms are larger, more capital intensive, and } \\
\text { more productive. Outsourcing itself has a positive impact on } \\
\text { firm productivity but not on plant-level productivity. }\end{array}$ \\
\hline $\begin{array}{l}\text { Moser, Urban, and } \\
\text { Weder di Mauro } \\
\text { (2009) }\end{array}$ & $\begin{array}{l}\text { Germany } \\
(1998-2004)\end{array}$ & $\begin{array}{l}\text { All sectors } \\
\text { (manufacturing } \\
\text { treated separately) }\end{array}$ & $\begin{array}{l}\text { Offshoring can reduce employment if it leads to downsizing } \\
\text { of firms. But the lower cost and greater competitiveness on } \\
\text { account of offshoring can lead to firm growth. Overall, } \\
\text { increase in the foreign intermediate input share in total } \\
\text { inputs has a significant positive impact on employment. }\end{array}$ \\
\hline Olsen (2006) & Meta-analysis & & $\begin{array}{l}\text { As such, there is no clear pattern as to how offshore out- } \\
\text { sourcing affects productivity, and the likelihood or extent of } \\
\text { gains depends on firm-level and industry-level characteristics. } \\
\text { There is some evidence to suggest, however, that firms are } \\
\text { more likely to benefit from outsourcing if they are already } \\
\text { globally engaged. }\end{array}$ \\
\hline Tomiura (2007) & $\begin{array}{l}\text { Japan } \\
\text { (1998) }\end{array}$ & Manufacturing & $\begin{array}{l}\text { Firms with richer human skills or experience with FDI are } \\
\text { more likely to outsource. Further, firms are more likely to off- } \\
\text { shore their activities if they are more productive and if their } \\
\text { products are labor intensive. }\end{array}$ \\
\hline Wagner (2011) & $\begin{array}{l}\text { Germany } \\
(2001-03)\end{array}$ & Manufacturing & $\begin{array}{l}\text { Firms that offshore are larger, more productive, and more } \\
\text { export-oriented than their non-offshoring counterparts; i.e., } \\
\text { better firms self-select to offshore. There is no evidence of } \\
\text { causal effect of offshoring on employment. }\end{array}$ \\
\hline
\end{tabular}

way to ensure that income levels in these economies recover to a pre-crisis level in the foreseeable future (Bhaumik, 2011). At its heart, outsourcing involves firms specializing in activities in which they have core competence (or comparative advantage) and interfirm trade in goods and services made possible by the unbundling of the production process. ${ }^{-}$Hence, economic theory suggests that it should have a positive impact on firm-level productivity. $\underline{2}$

However, the evidence in the recent literature measuring the impact of outsourcing on productivity is somewhat mixed (Olsen, 2006). For example, Girma and Görg (2004) find that out- 


\section{Aubuchon, Bandyopadhyay, Bhaumik}

sourcing in the United Kingdom, which was at least in part a cost-reducing strategy, raised productivity for some domestic manufacturing industries, especially for exporters. The greater impact of outsourcing on the productivity of exporters is also confirmed for the United States by Kurz (2006), for Ireland by Görg, Hanley, and Strobl (2008), and for Germany by Wagner (2011). But Criscuolo and Leaver (2005) find that in the United Kingdom most of the benefits of outsourcing accrue to firms that are not globally engaged. Similarly, Amiti and Wei (2006) find that (service) outsourcing, which does not contribute to job losses, contributes to higher total factor productivity (TFP). And Egger and Egger's (2006) study of 12 European Union countries suggests that the impact of outsourcing can change over time: It can have a negative impact on the real value added of workers in the short run, but this impact can be positive in the long run. Table 1 summarizes the key literature results on the impact of outsourcing on employment and firm performance.

It is not difficult to comprehend why the benefits of outsourcing may be limited. It is well understood that firm managers have their own vested interests that have little to do with firm performance, are boundedly rational, or can underestimate the magnitude of the cost of managing the outsourcing process and the contract with the vendors relative to benefits (on account of hubris). Hence, the realized net benefits of outsourcing may be significantly lower than the expected net benefits. Barthélemy (2001), for example, estimates that the cost of monitoring information technology vendors and the cost of bargaining and renegotiating contracts with them can be as high as 8 percent of the annual contract amount. Furthermore, it is difficult to estimate the costs of switching from in-house information technology activities to an external vendor and switching from one vendor to another. The actual cost of managing the overall outsourcing process can, therefore, be considerably higher. The marginal impact of outsourcing on firm performance might, therefore, be insignificant.

As mentioned earlier, we extend the literature on the impact of outsourcing on firm-level productivity using plant-level data from the German manufacturing sector. The choice of the country is deliberate; Germany's ability to benefit from outsourcing is not fully obvious (Farrell, 2004). We begin by examining the extent of outsourcing in German industries and the trend in outsourcing over time. We use a number of measures for 1995, 2000, and 2005 to estimate the extent of outsourcing in German industries over time. We compare and contrast the extent of outsourcing between the manufacturing and services sectors and also among the industries within each of these sectors. Thereafter, we examine the changes in the extent of outsourcing in these industries during the 1995-2000 and 2000-2005 periods. Next, we estimate the impact of industry-level outsourcing intensity on plant-level labor productivity for 2000 and 2005. We find that (i) the extent of outsourcing is higher among manufacturing industries in Germany than among service industries and (ii) the outsourcing intensity of these industries did not change much between 1995 and 2005. We also find a significantly positive and economically meaningful impact of industry-level outsourcing intensity on plant-level labor productivity in Germany's manufacturing sector ${ }^{3}$ for both 2000 and 2005.

The rest of the paper is structured as follows: The next section discusses the empirical strategy and the data. In particular, we highlight the extent of (and trends in) outsourcing intensity among German industries during the 1995-2005 period. We then present the regression results on the impact of outsourcing on labor productivity. The final section presents our conclusion. 


\section{EMPIRICAL STRATEGY AND DATA}

\section{Empirical Strategy}

We model $(\log )$ labor productivity $(Y / L)$ as a function of $(\log )$ capital per employee $(K / L)$, capital quality $(K Q)$, labor skills $(L S)$, and a number of other plant-level control variables (included in vector $\mathbf{Z}$ ). Finally, we add a measure of outsourcing (OSS), discussed below, to the regression specification. Our regression mode, therefore, is as follows:

$$
\left(\frac{Y}{L}\right)_{i}=\alpha_{0}+\alpha_{1}\left(\frac{K}{L}\right)_{i}+\alpha_{2} K Q_{i}+\alpha_{3} L S_{i}+\beta^{\prime} Z+\gamma O S S_{i}+\varepsilon_{i},
$$

where $i$ refers to the $i$ th firm and $\varepsilon$ is the i.i.d. error term. Our empirical model, which examines the relationship between plant-level labor productivity and industry-level outsourcing intensity, is consistent with both the strand of literature that examines plant- (or firm-) level performance with country-level factors such as institutional quality (see Bhaumik et al., 2012, for a discussion of the literature) and the strand that examines the impact of industry-level outsourcing on micro variables such as individual wage rates (Geishecker and Görg, 2008).

We include in the vector $\boldsymbol{Z}$ controls for market competition (i.e., competition) and ownership (a dummy variable that takes the value 1 for foreign-owned plants), both of which can affect firm performance (Bhaumik and Estrin, 2007). The average value of the Herfindahl index for the 2000 sample of industries was 87, while that for the 2005 sample was 81 . Foreign-owned plants accounted for about 8 percent and 11 percent of these samples, respectively. In addition, we control for the presence of a works council in the plant. Available evidence suggests that works councils can facilitate efficient enforcement of contractual agreements between managers and workers and thereby contribute to greater productivity (Addison, Schnabel, and Wagner, 2001). About 41 percent of the plants in the 2000 sample had works councils, and the corresponding figure for 2005 was 46 percent. We also include in the vector a control for location (a dummy variable that takes the value 1 when a plant is located in Eastern Germany) and distinguish between heavy and light industries (a dummy variable that takes the value 1 for light industries). About 30 percent of the plants in the 2000 sample and 26 percent of the plants in the 2005 sample are located in Eastern Germany.

As discussed later, we are able to use cross-sectional data for 2000 and 2005 for our estimation. In keeping with the literature, we need to consider the possibility that capital per employee, capital quality, and labor skills are endogenous. We have therefore used a two-stage instrumental variable estimation process. In the first stage, the potentially endogenous variables have been instrumented by past values of these variables and other exogenous variables such as firm age. In the second stage, labor productivity (and profitability) have been regressed on the measure of outsourcing, the instrumented values of the (potentially) endogenous variables, and the other control variables. The first-stage regressions are reported in Appendixes A2 and A3.

\section{Measures of Outsourcing}

We generate measures of outsourcing using balance of payments and input-output tables; details are reported in Table 2. Broadly speaking, we build on the research of Feenstra and 


\section{Aubuchon, Bandyopadhyay, Bhaumik}

\section{Table 2}

\section{Alternative Measures of Outsourcing}

\section{Outsourcing measure Description}

$\mathrm{FH}$ Following the work of Feenstra and Hanson (FH, 1996, 1999), the first measure is calculated as the share of imported intermediate inputs to total non-energy inputs. FH do not have a direct measure of imported intermediate inputs from their data and, instead, estimate import intensity using final trade data from the IMF balance of payment statistics. A useful way to think about the FH measure is the sum of the input weight times import intensity, for all inputs into production. Thus, for each industry $i$, FH have

$$
\text { FH_OSS }{ }_{i}=\sum_{j} \frac{[\text { input purchases of good } j \text { by industry } i]}{[\text { total non-energy inputs by industry } i]} * \frac{[\text { imports of good } j]_{j}}{\left[\text { production }_{j}+\text { imports }_{j}-\text { exports }_{j}\right]} \text {, }
$$

where for our measure all data come from the OECD. Imports and total production come from the total inputoutput table, such that each row of the column "imports" represents the total amount of each sector that is imported into the country for the given year. The important distinction is that this quantity does not equal the column sum from the import input-output table.

$\mathrm{FH}$ consider only material purchases by manufacturing industries from other manufacturing industries. Presumably, this approach excludes input purchases from energy-intensive industries, such as ISIC code 8namely, coke, refined petroleum products, and nuclear fuel. By extending the analysis to all 48 ISIC industries, energy industries are included. For the sake of completeness, we calculate the FH measure two ways, both including and excluding energy input purchases in the numerator. The results remain qualitatively the same, except as expected, for the two largest industries 2 (mining and quarrying) and 8 (coke, refined petroleum products, and nuclear fuel).

FH_narrow $\quad$ FH also consider a narrow measure of outsourcing intensity, which consists of input purchases of goods within the same industry. This can be thought of as restricting input purchases to the diagonal of the input-output matrix. For the narrow measure of outsourcing, we do not make the distinction of energy/non-energy inputs in the numerator. A comparable comparison would be to simply exclude energy-intensive industries from consideration.

OECD Using the OECD input-output tables, we generate a direct measure of imported intermediate inputs, which is exactly what $\mathrm{FH}$ and others have tried to estimate, by multiplying total intermediate inputs by an import intensity factor calculated from final trade data. The OECD (2008) defines offshoring as the share of nonenergy imported intermediate inputs in total non-energy intermediate inputs:

OECD_OSS $S_{j}=\sum_{i} \frac{x_{m}^{i j}}{\left(x_{m}^{i j}+x_{d}^{i j}\right)}$,

where $x_{d}^{i j}$ and $x_{m}^{i j}$ are the domestic and imported intermediate inputs from sector $i$ to sector $j$, respectively, and $i$ excludes the energy sectors (mining and utility). The OECD ratios are expected to be slightly lower than the corresponding FH measures, since the FH measures use final data for imports and production. The final trade data also include value added from production and, hence, might overstate the importance of a given import.

OECD_narrow This is the equivalent of FH's narrow measure of outsourcing, whereby only imports from the same industry are taken into consideration. 
Table 2, cont'd

\section{Alternative Measures of Outsourcing}

\section{Outsourcing \\ measure}

GG

GG_narrow

\section{Description}

Geishecker and Görg (GG, 2008) construct a measure of outsourcing intensity by focusing on imported intermediate inputs but, in contrast to $\mathrm{FH}$, normalize by total industry output value. This is an attempt to reconcile the difference between offshoring and domestic outsourcing, since (as GG point out) an increase in domestic outsourcing will lower the OSS measure in the FH and OECD calculations. By including value added in the denominator, as part of total output, GG argue that an increase in industry-level domestic input purchases will be countered by a decrease in industry-level value added. Hence, the GG measure of outsourcing intensity is

$G_{-}$OSS $_{j}=\frac{\sum_{i} X_{m}^{i j}}{Y_{j}}$,

where $X_{m}^{i j}$ represents the value of imported intermediate inputs from industry $i$ to industry $j$ and $Y_{j}$ represents the total output value of the industry of interest. Note that, in contrast to FH, GG choose to include energy purchases in the denominator.

This is the equivalent of FH's narrow measure of outsourcing, whereby only imports from the same industry are taken into consideration.

Hanson $(1996,1999)$ and define outsourcing as the share of imported intermediate inputs to total non-energy inputs. Our measures of outsourcing are a departure from the section of the literature that has used firm-level measures of outsourcing such as a firm-level binary indicator of change (increase) in the proportion of intermediate goods and services that are imported (Moser, Urban, and Weder di Mauro, 2009). The measures, however, are consistent with the wider literature on outsourcing and its impact on firm performance.

Table 3 shows the pairwise correlation among the different measures of outsourcing. With a few exceptions, the correlation coefficients are large and significant at the 10 percent level. Correlation is particularly high within wide and narrow measures of outsourcing. The observations made in the rest of this paper and the results reported should therefore not be influenced significantly by the choice of the outsourcing measure.

Figure 1 shows the Organisation for Economic Co-operation and Development (OECD) (standard or wide) measures of outsourcing for German manufacturing and service industries for 1995, 2000, and 2005. ${ }^{4}$ The extent of outsourcing is higher in manufacturing industries than in service industries. For most manufacturing industries, the measure of outsourcing is between 20 percent and 40 percent, while for most service industries it is below 20 percent. .5 Further, the outsourcing intensity in both manufacturing and service industries has remained stable since 1995 , suggesting that the popular wisdom that outsourcing is on the rise in developed country industries might require further investigation.

\section{Other Variables}

Estimating the impact of industry-level outsourcing intensity on plant-level labor productivity requires plant-level data on output, employment, location, ownership, etc. To this end, we use data provided by the Institute for Employment Research (IAB) at Nuremberg, Germany. 
Table 3

Correlations Among Alternative Measures of Outsourcing

\begin{tabular}{|c|c|c|c|c|c|c|}
\hline & OECD & OECD_narrow & GG & GG_narrow & FH & FH_narrow \\
\hline \multicolumn{7}{|l|}{1995} \\
\hline OECD & 1.00 & & & & & \\
\hline OECD_narrow & $0.58^{*}$ & 1.00 & & & & \\
\hline GG & $0.82^{*}$ & $0.61^{*}$ & 1.00 & & & \\
\hline GG_narrow & $0.62^{*}$ & $0.95^{*}$ & $0.55^{*}$ & 1.00 & & \\
\hline $\mathrm{FH}$ & 0.25 & $0.48^{*}$ & $0.72^{*}$ & $0.32^{*}$ & 1.00 & \\
\hline FH_narrow & $0.50^{*}$ & $0.89 *$ & $0.62^{*}$ & $0.88^{*}$ & $0.61 *$ & 1.00 \\
\hline \multicolumn{7}{|l|}{2000} \\
\hline OECD & 1.00 & & & & & \\
\hline OECD_narrow & $0.55^{*}$ & 1.00 & & & & \\
\hline GG & $0.74^{*}$ & $0.80^{*}$ & 1.00 & & & \\
\hline GG_narrow & $0.70^{*}$ & $0.83^{*}$ & $0.60^{*}$ & 1.00 & & \\
\hline $\mathrm{FH}$ & 0.12 & $0.61^{*}$ & $0.71^{*}$ & 0.15 & 1.00 & \\
\hline FH_narrow & $0.55^{*}$ & $0.86^{*}$ & $0.70^{*}$ & $0.85^{*}$ & $0.61 *$ & 1.00 \\
\hline \multicolumn{7}{|l|}{2005} \\
\hline OECD & 1.00 & & & & & \\
\hline OECD_narrow & $0.58^{*}$ & 1.00 & & & & \\
\hline GG & $0.60^{*}$ & $0.66^{*}$ & 1.00 & & & \\
\hline GG_narrow & $0.72^{*}$ & $0.92^{*}$ & $0.53^{*}$ & 1.00 & & \\
\hline $\mathrm{FH}$ & 0.18 & $0.51^{*}$ & $0.84^{*}$ & $0.28^{*}$ & 1.00 & \\
\hline FH_narrow & $0.61^{*}$ & $0.87^{*}$ & $0.72^{*}$ & $0.84^{*}$ & $0.64^{*}$ & 1.00 \\
\hline
\end{tabular}

Specifically, we use 2000 and 2005 rounds of the IAB Establishment Panel, a longitudinal survey that currently contains data on approximately 16,000 German firms (for details, see Fischer et al., 2008). The survey, which is the basis for a wide range of policy-related research, has two important limitations. First, because of a change in the classification system for economic activities, data are comparable for the 1993-99 period and thereafter for 2000 and the later years-hence our decision to restrict our analysis of labor productivity to 2000 and 2005 . Second, the data provide information about investment flows for the years of the survey; there is no information on capital stock. Since it is stylized to use capital stock as an explanatory variable in any regression model involving labor productivity, we had to compute plant-level capital stocks using other data sources.

We experimented with two different approaches to computing plant-level values of capital stock. We first used the German KLEMS data ${ }^{6}$ to compute industry-level capital-output ratios for 1995 and used these ratios to compute approximate values of plant-level capital stock, given data on plant-level output. We then used the data on investment flows and depreciation, and the perpetual inventory method, to compute plant-level values of capital stock for the subse- 


\section{Figure 1}

\section{OECD (standard) Measure of Outsourcing Intensity}

\section{Manufacturing industries, 1995 to 2005}

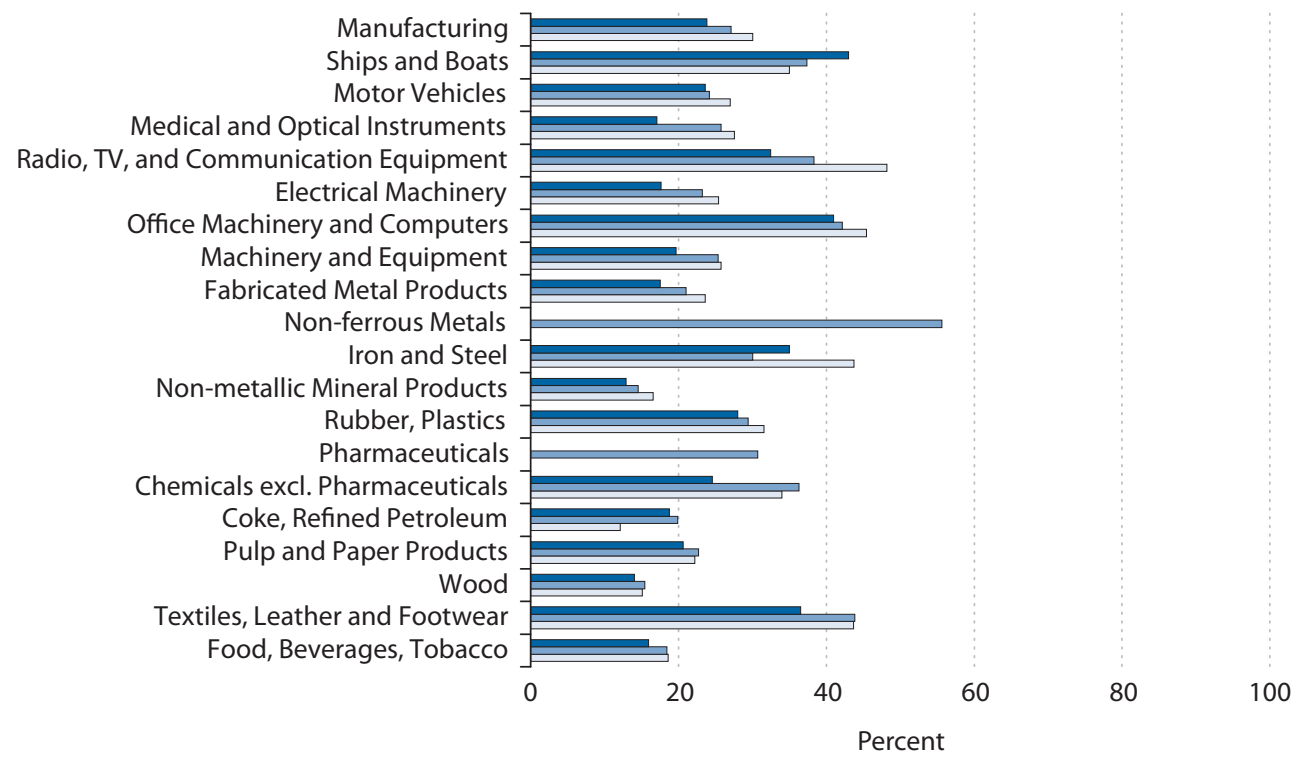

Service industries, 1995 to 2005

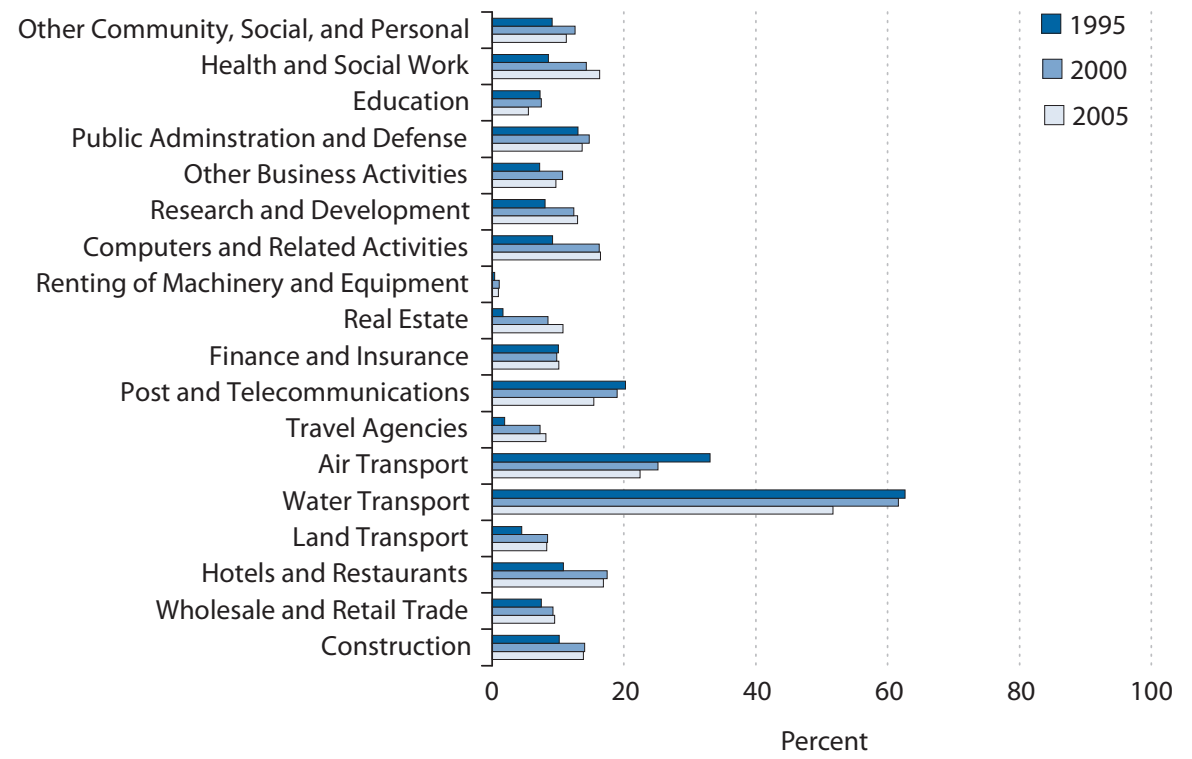




\section{Aubuchon, Bandyopadhyay, Bhaumik}

\section{Table 4}

Impact of Outsourcing on Labor Productivity

\begin{tabular}{|c|c|c|}
\hline & 2000 & 2005 \\
\hline Outsourcing & $\begin{array}{l}2.69^{* * * *} \\
(0.08)\end{array}$ & $\begin{array}{l}2.22^{* * * *} \\
(0.05)\end{array}$ \\
\hline \multicolumn{3}{|l|}{ Factor inputs } \\
\hline (Log) Capital per employee & $\begin{array}{l}0.97^{* * * *} \\
(0.005)\end{array}$ & $\begin{array}{l}0.95^{* * *} \\
(0.005)\end{array}$ \\
\hline Quality of capital & $\begin{array}{l}0.03^{* * *} \\
(0.007)\end{array}$ & $\begin{array}{l}0.03^{* * *} \\
(0.007)\end{array}$ \\
\hline Labor skill & $\begin{array}{c}0.002 \\
(0.02)\end{array}$ & $\begin{array}{c}0.009 \\
(0.01)\end{array}$ \\
\hline \multicolumn{3}{|l|}{ Other controls } \\
\hline Market concentration & $\begin{array}{c}-0.0004^{* * *} \\
(0.00003)\end{array}$ & $\begin{array}{c}-0.0003^{* * *} \\
(0.00002)\end{array}$ \\
\hline East German location & $\begin{array}{r}0.007 \\
(0.01)\end{array}$ & $\begin{array}{c}0.006 \\
(0.007)\end{array}$ \\
\hline Works council at the firm & $\begin{array}{c}-0.0004 \\
(0.007)\end{array}$ & $\begin{array}{l}0.02^{* * * *} \\
(0.007)\end{array}$ \\
\hline Foreign ownership & $\begin{array}{l}0.01 \\
(0.01)\end{array}$ & $\begin{array}{l}0.006 \\
(0.01)\end{array}$ \\
\hline Light industry & $\begin{array}{l}0.09^{* * * *} \\
(0.01)\end{array}$ & $\begin{array}{l}0.17^{* * * *} \\
(0.01)\end{array}$ \\
\hline Constant & $\begin{array}{l}-4.59^{* * *} \\
(0.05)\end{array}$ & $\begin{array}{l}-4.43^{* * *} \\
(0.05)\end{array}$ \\
\hline Anderson chi-square statistic & $317.79^{* * *}$ & $553.44^{* * *}$ \\
\hline Sargan chi-square statistic & 0.21 & 0.11 \\
\hline F-statistic & $5748.77^{* * *}$ & $6713.96^{* * *}$ \\
\hline Centered $R$-squared & 0.98 & 0.97 \\
\hline No. of observations & 949 & 1899 \\
\hline
\end{tabular}

quent years. However, the generated data had high variance, and we therefore opted for a simpler method to compute plant-level capital stock for 2000 and 2005. Specifically, we used the industrylevel capital output ratios for 2000 and 2005, obtained from the German KLEMS data, to compute plant-level capital stocks for these years, given the data on plant-level output. Detailed information about industry classification that was necessary to match industry-level capitaloutput ratios generated from KLEMS data with plant-level information was provided by IAB.

The data for industry-level measures of competition, namely, the Herfindahl index, was provided by the German Monopolkommission. The Monopolkommission also provided information on industry classification used for computing the Herfindahl indexes. This enabled us to match the plant-level information to the data on industry-level competition. 


\section{REGRESSION RESULTS}

Our regression results are reported in Table 4. We report the regression results for 2000 and 2005 alone. As mentioned earlier, on account of a change in the classification system for economic activities, data are comparable for the 1993-99 period and thereafter for 2000 and the later years. Further, as explained in footnote 5, we use lagged values of variables to instrument potential endogenous variables, and absence of lagged values of appropriate variables limits our ability to estimate a two-stage least-squares model for 1995. For 2000 and 2005, the F-statistics suggest that the estimated models are very meaningful in the context of the data. Indeed, despite the reduced efficiency of the regressions, on account of instrumenting, most of the explanatory variables are significant at the 1 percent level. Further, the statistics for the Anderson test for underidentification and the Sargan test for overidentifying restrictions suggest that the choice of instruments was appropriate. $\underline{\text { }}$

The results are also meaningful from the point of view of economic theory. They suggest that labor productivity is positively related to capital per employee and capital quality. The results indicate that the capital-per-employee elasticity of labor productivity is 0.97 ; that is, any increase in capital per employee results in a proportional change in labor productivity. The impact of capital quality on labor productivity is much weaker. Productivity is inversely related to market concentration; that is, it is higher in competitive markets. This is consistent with the wider literature on the impact of competition on productivity. Labor productivity is higher for firms in the light industries than those in the heavy industries. The link between works councils and productivity is not strong, but there is a significant positive relationship in 2005. This has interesting implications about the debate on the impact of labor market institutions on firm performance and is consistent with the argument that institutions that offer workers greater protection can improve productivity (Bhaumik et al., 2012).

Most importantly, outsourcing has both a statistically significant and economically meaningful impact on labor productivity. No other variable affects labor productivity as much; the impact of outsourcing is more than 2.5 times higher than the impact of the next most important factor, namely, capital per employee. This positive relationship between outsourcing and labor productivity is consistent with the evidence in the wider literature. As highlighted in Table 1, earlier research established a positive relationship between outsourcing and productivity (and its growth) in countries such as Ireland (Görg and Hanley, 2005) and the United Kingdom (Girma and Görg, 2004). While the overall evidence about the impact of outsourcing on productivity remains mixed, our results strengthen the arguments that emphasize the favorable aspects of outsourcing.

To recapitulate, our regression model has $(\log )$ labor productivity $(Y / L)$ as the dependent variable and a measure of outsourcing (OSS) that is bounded by zero and 1 as an explanatory variable. The marginal impact of outsourcing on labor productivity, therefore, is given by

$\frac{1}{Y / L} \frac{\partial(Y / L)}{\partial O S S}=2.69$ for 2000 and $\frac{1}{Y / L} \frac{\partial(Y / L)}{\partial O S S}=2.22$ for 2005 . At the mean value for labor productivity, therefore, the marginal impact of an increase in (industry level) outsourcing 


\section{Aubuchon, Bandyopadhyay, Bhaumik}

intensity on (plant level) labor productivity, $\frac{\partial(Y / L)}{\partial O S S}$, can be significant. This contradicts earlier findings that the marginal impact of outsourcing intensity on firm-level labor productivity is quite small (Criscuolo and Leaver, 2005). While it is not possible to reach strong conclusions on the impact of outsourcing on firm-level productivity based on a single empirical investigation, or indeed a handful of contradictory empirical results, our results suggest that there is scope for optimism about the beneficial aspects of outsourcing.

\section{CONCLUSION}

Outsourcing and offshoring have become increasingly volatile political issues in the developed economies of North America and Europe, in large measure on account of the rising or high and stagnant unemployment rates in these economies. Yet, the empirical literature on the impact of outsourcing on firms, while growing, is still somewhat small, and there is no consensus in this literature about the impact of outsourcing on firm performance. We extend this literature using plant-level data from the manufacturing sector in Germany, whose ability to benefit from outsourcing is not fully obvious. We find that the extent of outsourcing is higher among the manufacturing industries in Germany than among the service industries and that the outsourcing intensity of these industries did not change much between 1995 and 2005. We also find a significantly positive and economically meaningful impact of industry-level outsourcing intensity on plant-level labor productivity, for both 2000 and 2005.

Our research has certain shortcomings. We observe outsourcing intensity at the industry level rather than at the plant level, and we have a noisy measure of plant-level capital. However, our analysis provides some prima facie evidence about outsourcing intensity of German industries and the outsourcing-productivity link in Germany. It therefore provides the basis for further inquiry into the outsourcing phenomenon.

\section{NOTES}

1 The new institutional economics literature suggests that the choice between outsourcing and producing all components of the final product internally also depends on asset specificity of the intermediate products that are outsourced and the corresponding governance costs of the outsourcing contracts (Holmstrom and Roberts, 1998, and Williamson, 2002). Grossman and Helpman (2002) argue that the transactions cost approach to outsourcing is inadequate because it treats as given the industry environment within which a firm operates. They demonstrate that the extent of outsourcing depends on the search costs that are incurred by the firms to find appropriate vendors, the relative bargaining powers of the firms deciding on outsourcing and the vendors supplying the (intermediate) goods and services, and the elasticity of demand of the (final) consumer good. However, neither of these two strands of the literature discusses the impact of outsourcing on firm performance, especially productivity.

$\underline{2}$ The literature examines the impact of outsourcing both on firm- and plant-level productivity, and there is some indication that firm- and plant-level effects might indeed differ. We use plant-level data later in the article; however, in the discussion, we use "firm-level" and "plant-level" interchangeably.

3 To date, the majority of the economic literature has emphasized the impact of outsourcing on manufacturing firms (Olsen, 2006; Amiti and Wei, 2006; Görg and Hanley, 2005; Egger and Egger, 2006), but Daveri and Jona-Lasinio (2008) considered the impact of outsourcing manufacturing and services on the Italian economy between 1995 and 2003. They found that services outsourcing was not correlated with labor productivity but noted that their findings were 


\section{Aubuchon, Bandyopadhyay, Bhaumik}

not robust to different measures of services outsourcing. In keeping with the primary literature, and remaining cognizant of the potential for measurement error with service industries highlighted by Daveri and Jona-Lasinio (2008), we consider the impact of outsourcing on manufacturing firms.

4 The underlying figures for the manufacturing sector, which is the focus of our analysis, are reported in Appendix A1.

$\underline{5}$ The services sector outsources a wide range of services including ICT services, administrative services, sales, and after-sales services (through call centers, for example), etc. The U.S. financial services industry, for example, may have outsourced as much as 15 percent of their overall cost base (see Basel Committee on Banking Supervision, 2005).

6 The EU KLEMS Growth and Productivity Accounts contain industry-level data on output, inputs, and productivity for 25 European countries, Japan, and the United States. Details about the methodology used to assemble the data can be found in O'Mahony and Timmer (2009).

7 The first stage IV regressions for the three variables, which we treat as endogenous, namely, capital per employee $(K / L)$, capital quality $(K Q)$, and labor skill $(L S)$, are reported in Appendixes A2 and A3. The first stage IV regressions suggest that lagged values of the endogenous variables are generally the best instruments for the 2000 and 2005 values of these variables. The use of past values of variables as instruments is fairly common in the literature. We experimented with longer lags of these variables, but the use of the shorter (one-period) lag was sufficient for our purposes, and the use of such short lags is also desirable for the credibility of the two-stage least-squares estimates (see Murray, 2006).

\section{REFERENCES}

Addison, John T.; Schnabel, Claus and Wagner, Joachim. "Work Councils in Germany: Their Effects on Establishment Performance." Oxford Economic Papers, October 2001, 53(4), pp. 659-94.

Amiti, Mary and Wei, Shang-Jin. "Service Offshoring and Productivity: Evidence from the United States." NBER Working Paper No. 11926, National Bureau of Economic Research, October 2006; www.nber.org/papers/w11926.pdf.

Bachmann, Ronald and Braun, Sebastian. "The Impact of International Outsourcing on Labour Market Dynamics in Germany." Scottish Journal of Political Economy, February 2011, 58(1), pp. 1-28.

Basel Committee on Banking Supervision. "Outsourcing in Financial Services." Basel, Switzerland: Bank for International Settlements, February 2005; www.bis.org/publ/joint12.htm.

Barthélemy, Jérôme. "The Hidden Costs of IT Outsourcing." MIT Sloan Management Review, Spring 2001, 42(3), pp. 60-69.

Bhaumik, Sumon Kumar. "Productivity and the Economic Cycle." BIS Economics Paper No. 12, Bank for International Settlements Department for Business Innovation and Skills, March 2011; www.bis.gov.uk/assets/biscore/economics-and-statistics/docs/p/11-772-productivity-and-the-economic-cycle.

Bhaumik, Sumon Kumar; Dimova, Ralitza; Kumbhakar, Subal C. and Sun, Kai. “Does Institutional Quality Affect Firm Performance? Insights from a Semiparametric Approach." IZA Discussion Paper No. 6351, Institute for the Study of Labor, 2012; http://ftp.iza.org/dp6351.pdf.

Bhaumik, Sumon Kumar and Estrin, Saul. "How Transition Paths Differ: Enterprise Performance in Russia and China." Journal of Development Economics, March 2007, 82(2), pp. 374-92.

Criscuolo, Chiara and Leaver, Mark. "Offshore Outsourcing and Productivity." Unpublished manuscript, 2005; www.oecd.org/dataoecd/55/23/35637436.pdf.

Daveri, Francesco and Jona-Lasinio, Cecilia. "Off-Shoring and Productivity Growth in the Italian Manufacturing Industry." CESifo Economic Studies, September 2008, 54(3), pp. 414-50.

Directorate-General for Economic and Financial Affairs. "Impact of the Current Economic and Financial Crisis on Potential Output." Occasional Paper No. 49, European Commission, June 2009; http://ec.europa.eu/economy finance/publications/publication15479 en.pdf.

Egger, Hartmut and Egger, Peter H. "International Outsourcing and the Productivity of Low-Skilled Labor in the EU." Economic Inquiry, January 2006, 44(1), pp. 98-108.

Farrell, Diana. “Can Germany Win from Offshoring?” McKinsey Global Institute, July 2004. 


\section{Aubuchon, Bandyopadhyay, Bhaumik}

Feenstra, Robert C. and Hanson, Gordon H. "Globalization, Outsourcing, and Wage Inequality." American Economic Review, May 1996, 86(2), pp. 240-45.

Feenstra, Robert C. and Hanson, Gordon H. "The Impact of Outsourcing and High-Technology Capital on Wages: Estimates for the United States, 1979-1990." Quarterly Journal of Economics, August 1999, 114(3), pp. 907-40.

Fischer, Gabriele; Janik, Florian; Müller, Dana and Schmucker, Alexandra. "The IAB Establishment Panel—From Sample to Survey to Projection." FDZ Working Paper No. 01/2008, The Research Data Centre (FDZ) of the Federal Employment Service, Institute for Employment Research, 2008; http://doku.iab.de/fdz/reporte/2008/MR 01-08 en.pdf.

Furceri, Davide and Mourougane, Annabelle. "The Effect of Financial Crises on Potential Output: New Empirical Evidence from OECD Countries." OECD Economics Department Working Paper No. 699, OECD, Organisation for Economic Co-operation and Development, 2009; www.oecd-ilibrary.org/docserver/download/fulltext/5ksj3lqk2h40.pdf?expires=1338557881\&id=id\&accname= guest\&checksum=A58AA934D8DDFEDAC96BD882A2849DCC.

Geishecker, Ingo and Görg, Holger. "Winners and Losers: A Micro-Level Analysis of International Outsourcing and Wages." Canadian Journal of Economics, February 2008, 41(1), pp. 243-70.

Girma, Sourafel and Görg, Holger. “Outsourcing, Foreign Ownership, and Productivity: Evidence from UK Establishment-Level Data." Review of International Economics, November 2004, 12(5), pp. 817-32.

Görg, Holger and Hanley, Aoife. "Does Outsourcing Increase Profitability." Economic and Social Review, 2004, 35(3), pp. 267-88.

Görg, Holger and Hanley, Aoife. "International Outsourcing and Productivity: Evidence from the Irish Electronics Industry." North American Journal of Economics and Finance, August 2005, 16(2), pp. 255-69.

Görg, Holger; Hanley, Aoife and Strobl, Eric. "Productivity Effects of International Outsourcing: Evidence from PlantLevel Data." Canadian Journal of Economics, May 2008, 41(2), pp. 670-688.

Görzig, Bernd and Stephan, Andreas. "Outsourcing and Firm-Level Performance." Discussion Paper No. 309, DIW Berlin, German Institute for Economic Research, October 2002; http://repec.org/res2003/Gorzig.pdf.

Grossman, Gene M. and Helpman, Elhanan. "Integration Versus Outsourcing in Industry Equilibrium." Quarterly Journal of Economics, February 2002, 117(1), pp. 85-120.

Hijzen, Alexander; Inui, Tomohiko and Todo, Yasuyuki. "Does Offshoring Pay? Firm-Level Evidence from Japan." Economic Inquiry, October 2010, 48(4), pp. 880-95.

Holmström, Bengt and Roberts, John. "The Boundaries of the Firm Revisited." Journal of Economic Perspectives, Fall 1998, 12(4), pp. 73-94.

Keuschnigg, Christian and Ribi, Evelyn. "Outsourcing, Unemployment and Welfare Policy." Journal of International Economics, June 2009, 78(1), pp. 168-76.

Kurz, Christopher J. "Outstanding Outsourcers: A Firm- and Plant-Level Analysis of Production Sharing." Finance and Economics Discussion Series Working Paper No. 2006-04, Division of Research \& Statistics and Monetary Affairs, Board of Governors of the Federal Reserve System, 2006; www.federalreserve.gov/pubs/feds/2006/200604/200604pap.pdf.

Moser, Christoph; Urban, Dieter and Weder di Mauro, Beatrice. "Offshoring, Firm Performance and Establishment-Level Employment: Identifying Productivity and Downsizing Effects." CEPR Discussion Paper No. DP7455, Centre for Economic Policy Research, September 2009.

Murray, Michael P. "Avoiding Invalid Instruments and Coping with Weak Instruments." Journal of Economic Perspectives, Fall 2006, 20(4), pp. 111-32.

O'Mahony, Mary and Timmer, Marcel P. "Output, Input and Productivity Measures at the Industry Level: The EU KLEMS Database." Economic Journal, June 2009, 119(538), pp. F374-F403.

Olsen, Karsten B. “Productivity Impacts of Offshoring and Outsourcing: A Review." STI Working Paper No. 2006/1, OECD Directorate for Science, Technology and Industry (STI), Organisation for Economic Co-operation and Development, March 2006; www.oecd.org/dataoecd/16/29/36231337.pdf.

Tomiura, Eiichi. "Foreign Outsourcing, Exporting, and FDI: A Productivity Comparison." Journal of International Economics, May 2007, 72(1), pp. 113-27. 
Wagner, Joachim. "Offshoring and Firm Performance: Self-Selection, Effects on Performance, or Both?" Review of World Economics, June 2011, 147(2), pp. 217-47.

Williamson, Oliver E. "The Theory of the Firm as Governance Structure: From Choice to Contract." Journal of Economic Perspectives, Summer 2002, 16(3), pp. 171-95.

Wilmot, Jill. "Outsourcing Is Key to Surviving the Downturn: The Capgemini Executive Outsourcing Survey Conducted by Harris Interactive." Capgemini, 2009; www.us.capgemini.com/insights-resources/publications/outsourcing-iskey-to-surviving-the-downturn-the-capgemini-executive-outsourcing-survey-conducted-by-harris-interactive/.

Zhang, Ting. "International Outsourcing and Unemployment in a Minimum-Wage Economy." Review of International Economics, September 2011, 19(4), pp. 776-86. 


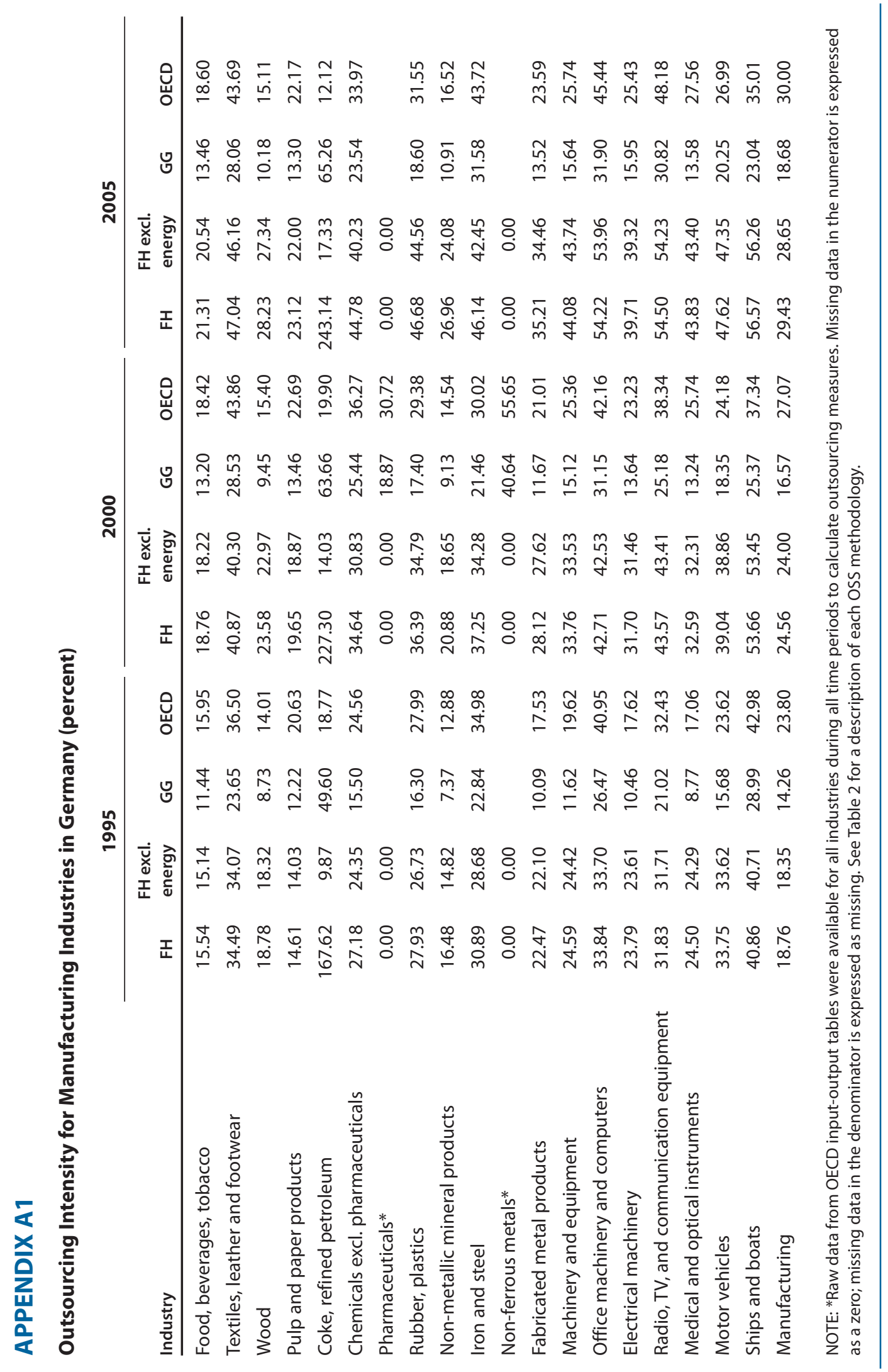




\section{APPENDIX A2}

First Stage IV Regressions for 2000

\begin{tabular}{|c|c|c|c|}
\hline & K/L & KQ & LS \\
\hline Firm age & $\begin{array}{c}0.03 \\
(0.02)\end{array}$ & $\begin{array}{c}0.06 \\
(0.05)\end{array}$ & $\begin{array}{l}0.04^{* * *} \\
(0.01)\end{array}$ \\
\hline Outsourcing & $\begin{array}{c}-0.38 \\
(0.24)\end{array}$ & $\begin{array}{c}0.57 \\
(0.50)\end{array}$ & $\begin{array}{c}0.14 \\
(0.13)\end{array}$ \\
\hline Market concentration & $\begin{array}{c}0.0001 \\
(0.0001)\end{array}$ & $\begin{array}{c}0.00004 \\
(0.0002)\end{array}$ & $\begin{array}{c}-0.00001 \\
(0.00005)\end{array}$ \\
\hline East German location & $\begin{array}{l}-0.12^{* * *} \\
(0.03)\end{array}$ & $\begin{array}{c}-0.03 \\
(0.06)\end{array}$ & $\begin{array}{c}0.02 \\
(0.01)\end{array}$ \\
\hline Foreign ownership & $\begin{array}{c}-0.02 \\
(0.03)\end{array}$ & $\begin{array}{c}-0.07 \\
(0.07)\end{array}$ & $\begin{array}{c}-0.03 \\
(0.02)\end{array}$ \\
\hline Works council at the firm & $\begin{array}{l}0.11^{* * *} \\
(0.02)\end{array}$ & $\begin{array}{l}-0.04 \\
(0.05)\end{array}$ & $\begin{array}{c}0.01 \\
(0.01)\end{array}$ \\
\hline Light industry & $\begin{array}{c}0.02 \\
(0.03)\end{array}$ & $\begin{array}{c}0.08 \\
(0.06)\end{array}$ & $\begin{array}{c}-0.01 \\
(0.02)\end{array}$ \\
\hline (Lag) Capital per employee & $\begin{array}{l}0.90 * * * \\
(0.01)\end{array}$ & $\begin{array}{c}0.05^{*} \\
(0.03)\end{array}$ & $\begin{array}{l}0.02^{* *} \\
(0.01)\end{array}$ \\
\hline (Lag) Capital quality & $\begin{array}{c}0.001 \\
(0.01)\end{array}$ & $\begin{array}{l}0.56^{* * *} \\
(0.02)\end{array}$ & $\begin{array}{c}0.006 \\
(0.007)\end{array}$ \\
\hline (Lag) Labor skill & $\begin{array}{c}0.02 \\
(0.04)\end{array}$ & $\begin{array}{c}-0.13 \\
(0.08)\end{array}$ & $\begin{array}{l}0.70 * * * \\
(0.02)\end{array}$ \\
\hline Constant & $\begin{array}{l}0.88^{* * *} \\
(0.16)\end{array}$ & $\begin{array}{c}1.07 \\
(0.32)\end{array}$ & $\begin{array}{c}-0.12 \\
(0.08)\end{array}$ \\
\hline F-statistic & $580.29 * * *$ & $52.02 * * *$ & $115.01^{* * *}$ \\
\hline Centered $R$-squared & 0.86 & 0.35 & 0.55 \\
\hline
\end{tabular}

NOTE: The values within parentheses are robust standard errors; ${ }^{* * *},{ }^{* *}$, and ${ }^{*}$ indicate significance at the 1,5 , and 10 percent levels, respectively. 
Aubuchon, Bandyopadhyay, Bhaumik

\section{APPENDIX A3}

First Stage IV Regressions for 2005

\begin{tabular}{|c|c|c|c|}
\hline & $K / L$ & KQ & LS \\
\hline Firm age & $\begin{array}{c}-0.0009 \\
(0.01)\end{array}$ & $\begin{array}{c}0.02 \\
(0.03)\end{array}$ & $\begin{array}{l}0.04^{* * *} \\
(0.01)\end{array}$ \\
\hline Outsourcing & $\begin{array}{c}-0.21^{*} \\
(0.12)\end{array}$ & $\begin{array}{c}0.03 \\
(0.02)\end{array}$ & $\begin{array}{c}0.03 \\
(0.07)\end{array}$ \\
\hline Market concentration & $\begin{array}{c}0.00005 \\
(0.00006)\end{array}$ & $\begin{array}{c}0.00001 \\
(0.0001)\end{array}$ & $\begin{array}{c}-0.00003 \\
(0.00003)\end{array}$ \\
\hline East German location & $\begin{array}{l}-0.05^{* * *} \\
(0.02)\end{array}$ & $\begin{array}{c}0.04 \\
(0.03)\end{array}$ & $\begin{array}{c}0.009 \\
(0.01)\end{array}$ \\
\hline Foreign ownership & $\begin{array}{c}0.04^{*} \\
(0.02)\end{array}$ & $\begin{array}{c}-0.09^{*} \\
(0.05)\end{array}$ & $\begin{array}{c}-0.004 \\
(0.01)\end{array}$ \\
\hline Works council at the firm & $\begin{array}{l}0.11^{* * * *} \\
(0.02)\end{array}$ & $\begin{array}{c}-0.06 \\
(0.03)\end{array}$ & $\begin{array}{c}0.003 \\
(0.01)\end{array}$ \\
\hline Light industry & $\begin{array}{c}-0.01 \\
(0.02)\end{array}$ & $\begin{array}{c}-0.07 \\
(0.05)\end{array}$ & $\begin{array}{c}-0.02 \\
(0.01)\end{array}$ \\
\hline (Lag) Capital per employee & $\begin{array}{l}0.88^{* * * *} \\
(0.01)\end{array}$ & $\begin{array}{l}0.09^{* * * *} \\
(0.02)\end{array}$ & $\begin{array}{c}0.007 \\
(0.006)\end{array}$ \\
\hline (Lag) Capital quality & $\begin{array}{l}0.02^{*} \\
(0.0009)\end{array}$ & $\begin{array}{l}0.55^{* * *} \\
(0.02)\end{array}$ & $\begin{array}{c}-0.009 * \\
(0.005)\end{array}$ \\
\hline (Lag) Labor skill & $\begin{array}{l}0.07^{* * * *} \\
(0.02)\end{array}$ & $\begin{array}{c}-0.005 \\
(0.05)\end{array}$ & $\begin{array}{l}0.70^{* * * *} \\
(0.02)\end{array}$ \\
\hline Constant & $\begin{array}{l}0.87^{* * *} \\
(0.11)\end{array}$ & $\begin{array}{c}0.92 \\
(0.23)\end{array}$ & $\begin{array}{c}0.07 \\
(0.06)\end{array}$ \\
\hline F-statistic & $1201.19^{* * *}$ & $88.49 * * *$ & $216.90^{* * *}$ \\
\hline Centered $R$-squared & 0.86 & 0.32 & 0.53 \\
\hline
\end{tabular}




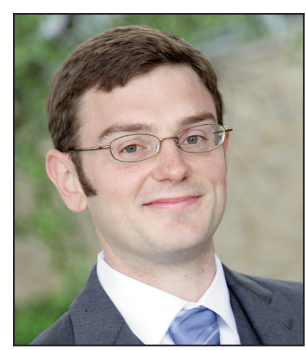

\section{Craig Aubuchon}

Indiana University School of Public and Environmental Affairs

\section{Research Focus}

Craig Aubuchon was a research associate with the Federal Reserve Bank of St. Louis from 2007 to 2010. He recently graduated from Indiana University with master's degrees in public administration and environmental science. His current research uses benefit-cost analysis and applied econometrics to understand the economic value of water resources.

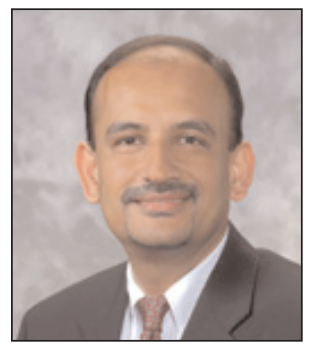

\section{Subhayu Bandyopadhyay}

Research officer and economist, Federal Reserve Bank of St. Louis

http://research.stlouisfed.org/econ/bandyopadhyay/

\section{Research Focus}

Subhayu Bandyopadhyay's main areas of research are international trade theory and international development. His recent research also includes contributions to the economic analysis of terrorism.

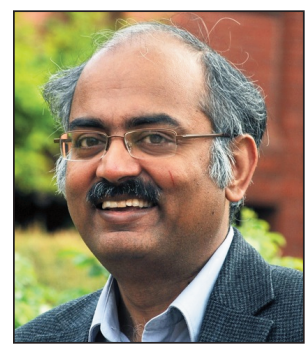

\section{Sumon Kumar Bhaumik}

Reader in the Economics and Strategy Group, Aston Business School, Aston University, Birmingham, U.K.

\section{Research Focus}

Sumon Bhaumik's research encompasses a number of areas within economics, finance, and international business. In the recent past, his research has focused on implications of ownership structures on both performance (e.g., M\&A outcomes) and strategic decisions (e.g., likelihood and direction of overseas investment) of firms. He has also examined issues such as financing constraints among firms and cross-ownership differences in the impact of monetary policy on credit disbursal by banks. 